\title{
The Impact of Legalized Prostitution on Human Trafficking
}

\author{
Egzone Osmanaj, Phd.(Cand).
}

egzona.osmanaj@evun.eu

\section{Doi:10.5901/ajis.2014.v3n2p103}

\section{Abstract}

Trafficking in persons is a phenomenon that has taken dimensions that are always increasing and it is considered as a slavery of modern times. Trafficking in persons is treated as a basic violation of substantial human rights of an individual, since it violates the dignity and human integrity. Trafficking of children, women and young girls is not only connected to prostitution or their use for sex, but also with many social problems. Trafficking of human beings originates from a series of social and psychological conditions. This work treats the legalization of prostitution and its relation to the traffickingin persons. The basic intention of this work is to analyze whether there is influence or not on the reduction of trafficked persons by the legalization of the prostitution. The questions that we intend to give answers through this work based on experts' opinions and results of different scientific researches shall be as follows; - Legalization of prostitution effects on the increase or decrease on trade with humans. - Legalization of prostitution,does it controls the sex industry or it expands it even more. - Taxation aspect of the prostitution: the motive of legalization of the prostitution: for the benefit of the state or for the benefit of the citizens? For analysis we shall take example to study the Dutch and German models of prostitution, these models have accepted prostitutionas as a legal activity, actually we shall compare them with Swedish model of prostitution, with the aim to get an exact conclusion of how much there could be influence on increase or decrease of trafficked persons by legalizing the prostitution.

Keywords: Impact,legalization ,prostitution, trafficking.

\section{Introduction}

The following work shall speak about the influence that legalization of prostitution might have on increase or decrease of the number of trafficked people. Human trafficking is developed on all of its forms, but the most spread version is the one for sexual exploitation, because it is considered to be lucrative and less dangerous compared to other forms of trafficking like smuggling weapons or narcotic substances.Many authors claim that the women market is transformed in a global business, where annual incomes from this business reach amounts of several billion dollars annually.Based on this situation, many international organizations, especially those that deal with protection of women rights, raised the need to legalize prostitution in order to reduce the number of trafficked humans for sexual use, thus to protect the sex workers so that they shall not be discriminated but treated equally as other workers that work at another activity. Different countries in the world have different policies against this phenomenon, in some countries prostitution is completely legal (in all forms), in some countries only some forms of prostitution are legalized, whilst in some countries prostitution is considered completely illegal.

The main intention of this work is to analyze the relationship between legalization of prostitution and human trafficking, respectively to explain if legalization of prostitution could affect the increase or decrease on trafficking in persons with the intention of sexual exploitation.

The methodology used in this work is based in a wide bibliography of books, studies, scientific articles that refer to trafficking in persons, respectively trafficking in persons for sexual exploitation.

The hypotheses raised in this work are as follows:

- Legalization of prostitution does not effect on the decrease of number of trafficked humans;

- Legalization of prostitution does not control the sex industry, but it expands it even more.

- Legalization of prostitution increases the illegal prostitution. 


\section{The Impact of Legalized Prostitution on Human Trafficking}

\subsection{Notion of trafficking in persons}

Trafficking in persons is demonstrated as a global criminal phenomenon. In South Eastern Europe after trafficking with drugs, trafficking in persons is one of the most lucrative activities of organized crime. In different international instruments, trafficking in persons is considered as "a violation of substantial human rights, dignity and integrity of human beings". In order to be able to analyze the influence of prostitution legalization in the increase or decrease of the number of trafficked humans, first it is necessary to determine the notion trafficking with human beings. The protocol of United Nations Organization for Prevention, Stopping and Punishing Trafficking with Human Begins, especially women and children (Protocol for Trafficking), in article 3 (point a.),considers that:Trafficking in persons" shall mean the recruitment, transportation, transfer, harbouring or receipt of persons, by means of the threat or use of force or other forms of coercion, of abduction, of fraud, of deception, of the abuse of power or of a position of vulnerability or of the giving or receiving of payments or benefits to achieve the consent of a person having control over another person, for the purpose of exploitation.(Protocol to Prevent, Suppress and Punish Trafficking in Women and Children, supplementary to the United Nations Convention against Transnational Organized Crime, UN Doc. A/55/383 (15 december 2000), entered into force on $25^{\text {th }}$ of December 2003.)

In completely similar manner trafficking ib humans is defined also in the Convention of Europe Council against trafficking in humans.The same definition is used in the Criminal Code of Kosovo in article 139 using the words that are in the mentioned determination, determines trafficking in persons as the recruitment, transportation, transfer, harboring or receipt of persons, by threat or the use of force or other forms of coercion, abduction, fraud, deception, the abuse of power or the abuse of a position of vulnerability or the giving or receiving of payments or benefits to achieve the consent of a person having control over another person, for the purpose of exploitation. Taking into account the above determination, as key elements of trafficking in persons are considered;

- The offence:Recruitment transferring, harboring or receipt of persons.

- Illegal ways (means) : threat or use of violence or other forms of compulsion, abduction, falsification, fraud, use of power,position or any sensitive position or by giving or receiving payments or benefits to achieve the consent ofa person having control over another person,

- Intention: means exploitation of another person. The word exploitation is determined among others includes prostitution of others, pornography or other forms of sexual exploitation, begging, forced or compulsorylabor or services, slavery or practices similar to slavery, servitude or the removal of organs or tissue.

\subsection{Forms of human trafficking}

Trafficking with human beings is demonstrated in exploitations ways like:

- Prostitution and other sexual services;

- Forced labor;

- Donation of organs;

- Forced military service;

- Negotiated marriages.

\subsection{The causes of trafficking in persons}

Many authors depending on their theoretical access identify a series of causes for trafficking in persons. The causes (factors) for trafficking in persons are divided into two main groups: a propulsion factor and attraction factor.As a propulsion factor are considered to be: the differences in economic development of the countries; unemployment; poverty; rough regime; emigration set by the stronger and developed countries, lack of opportunities and perspective; lack of knowledge and lack of information about the dangers and consequences of the trafficking; low education level especially in rural areas. Whereas the attractive factors are considered to be: the employment hope and of a better life; reliable job market in the countries of the destination; a glimmering advertisement of life in western countries; Continuous demand for cheap labor force, etc.("Fuqizimi i Kapaciteteve Shqiptare Kundër Trafikimit" 2013,P,7). Thus, the factors of trafficking in persons can be divided into three groups: economic factors, social factors, and political factors. 


\subsection{International legal frame}

Trafficking in persons is a very serious global problem that is always increasing worldwide. Therefore all important international organizations starting from United Nations Organization and to the regional organizations have ratified different conventions for protection against trafficking. The following table contains some of the most important international conventions.

Table 1. Differentregional and global conventions for protection against trafficking.

\begin{tabular}{|c|c|c|c|c|c|c|c|}
\hline & Year & $\begin{array}{c}\text { Main } \\
\text { organization }\end{array}$ & $\begin{array}{l}\text { Regional } \\
\text { or global }\end{array}$ & $\begin{array}{l}\text { Relevant } \\
\text { articles }\end{array}$ & Ratifications & Obligations & Focus \\
\hline Convention on forced labor & 1932 & ILO & Globale & All & 172 & Yes & Wide \\
\hline Convention on disappearance of Forced Labor & 1957 & ILO & Globale & All & 167 & Yes & Wide \\
\hline Convention on children Rights. & 1990 & UNCR & Globale & $\begin{array}{c}\text { Articles 11, 19, } \\
32,34-39\end{array}$ & 193 & Yes & Children \\
\hline $\begin{array}{l}\text { African Charter on the rights and well-being of the } \\
\text { Child }\end{array}$ & 1990 & UA & Regional & $\begin{array}{c}\text { Articles } 15,22, \\
27,29\end{array}$ & 35 & Yes & Children \\
\hline Convention on the worse forms of child labor. & 2000 & ILO & Regional & All & 165 & Yes & Children \\
\hline $\begin{array}{l}\text { Optional Protocol of the Convention for the rights } \\
\text { of the Child and their involvement in armed } \\
\text { conflicts }\end{array}$ & 2000 & UNCR & Globale & All & 117 & Yes & Children \\
\hline $\begin{array}{l}\text { Protocol of united nations on prevention, } \\
\text { suppression and punishment of trafficking in } \\
\text { persons especially women and children. }\end{array}$ & 2000 & UNODC & Globale & All & 115 & Yes & Wide \\
\hline Statement of ECOËAS on War Against Trafficking & 2001 & ECOËAS & Regional & All & 15 & No & Wide \\
\hline $\begin{array}{l}\text { Optional Protocol on the sale of children, child } \\
\text { prostitution and child pornography }\end{array}$ & 2002 & UNCR & Globale & All & 121 & Yes & Children \\
\hline Bali-t II Agreement & 2003 & ASEAN & Regional & All & 10 & No & Wide \\
\hline $\begin{array}{l}\text { Convention of European Council Against } \\
\text { Trafficking in Persons }\end{array}$ & 2005 & COE & Regional & All & 9 & Yes & Wide \\
\hline
\end{tabular}

Source: http://www.dcaf.ch/content/download/35416/526049/file/ALB

\section{Legalization of Prostitution and Its Influence in Trafficking in Persons}

\subsection{Trafficking in persons with the intention of sexual abuse dominant in comparison to other forms of trafficking}

Trafficking in persons is treated today as one of the priority problems of the society. In different international instruments, trafficking in persons is considered as "a violation of substantial human rights, dignity, and integrity of human beings".("Fuqizimi i Kapaciteteve Shqiptare Kundër Trafikimit" 2013,P,5).According to the European Commission (2009), trafficking in persons is a serious crime and a gross violation of human rights. In the statute of International Criminal Court, article 7.2 trafficking in persons is considered as a crime against humanity.Governments in the entire world see the trafficking in persons as a component of organized crime and the average punishment for trafficking in persons is comparable to other types of serious transnational crimes.(Jakobsson.N.and Kotsadam.A. 2010 P.2).According to the global report of 2008 for trafficking in persons, published by United Nations Office on Drugs and Crime (UNODC),millions of people are victims of trafficking every year. In this trade around 79 percent are trafficked for sexual services, whereas 18 percent for violent work. According to the estimations that UNO has made, only in USA every year more than 50 thousand sold women enter USA,that mainly come from Ukraine, Albania, Philippines, Thailand,Mexico and Nigeria. Women from China,Malaysia, Indonesia, South Korea, Columbia, Vietnam, etc. are sold to Australia and elsewhere, for sexual use and pornography.(Sokoli,L.and Sokoli,I, 2006 P.13).So, trafficking for prostitution purposes (sexual exploitation) makes the most spread form of trafficking in persons. It is opined that trafficking for prostitution keeps the dominance compared to other forms because: it is considered that it provides huge incomes (the value of sex commodity is estimated to be up to 12 billion America dollars); it is considered to be less dangerous compared to other forms of trafficking like smuggling weapons or narcotic substances and easier to be carried out because usually the victim of 
trafficking for prostitution are mainly women with low level of education and that live in difficult economic conditions , therefore these women very easily can be manipulated with a hope for a better life.Many organizations that deal with protection of human rights see the legalization often prostitution as a solution of the problem of trafficking in persons for sexual exploitation in their countries. Representatives of different organizations say that sex workers need protection and security because they are often target of abuse and rape from different unscrupulous persons. Thus the Commission of United Nations for "HIV" and "LAWS", in a special report requested from all countries to dismiss laws that prohibit prostitution ${ }^{1}$.According to UNO,"With current laws of many countries of the world prostitution is criminalized. However this activity is done illegally,whereas poor medical services increase the risk of infection with deadly virus. UNO estimates that legalization of prostitution would create conditions for regular inspection, for better medical services, would minimize trafficking in persons and would save hundreds of thousands of people from infection danger of HIVIAIDS.(UNO Report,2012).Different countries of the world have different politics against this phenomenon, thus in some countries the phenomenon of prostitution are completely legal (on all of its forms), and in some countries only some forms of prostitution are legal whilst in others it is completely forbidden.
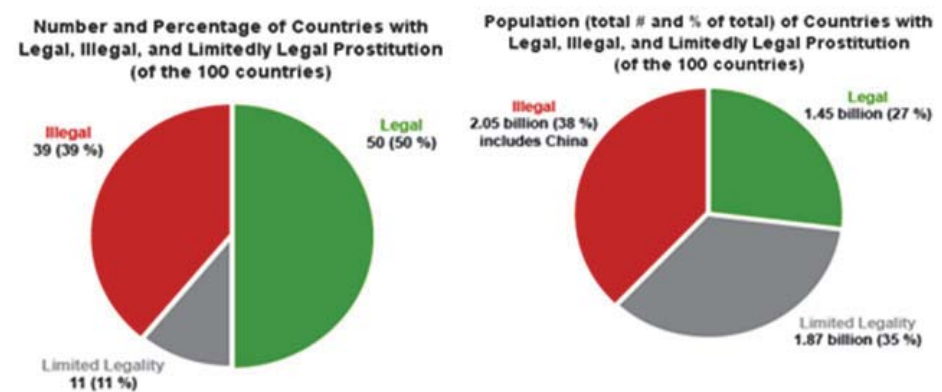

Fig.1 Number and percentage of countries with legal, illegal and limited prostitution of 100 countries. (Source: http://prostitution.procon.org/view.resource.php?resourcelD=000772).

Table 2.100 Countries and their prostitution policies.

100 Countries and Their Prostitution Policies

\begin{tabular}{lll}
\hline Legal in $50(50 \%)$ & Limited Legality in $11(11 \%)$ & Illegal in $39(39 \%)$ \\
\hline Argentina & Australia & Afghanistan \\
Armenia & Bangladesh & Albania \\
Austria & Iceland & Angola \\
Belgium & India & Antigua and Barbuda \\
Belize & Japan & Bahamas \\
Bolivia & Malaysia & Barbados \\
Brazil & Norway & Cambodia \\
Canada & Spain & China (including Taiwan) \\
Chile & Sweden & Croatia \\
Colombia & United States & Cuba \\
Costa Rica & & Dominica \\
Cyprus & & Egypt \\
Czech Republic & & Grenada \\
Denmark & & Guyana \\
Dominican Republic & & Haiti \\
Ecuador & & Iran \\
El Salvador & & Iraq \\
Estonia & & Jamaica \\
Ethiopia & & Jordan \\
Finland & & Kenya \\
France & Korea, North \\
Germany & Korea, South \\
\hline
\end{tabular}




\begin{tabular}{ll} 
Greece & Liberia \\
Guatemala & Lithuania \\
Honduras & Malta \\
Hungary & Philippines \\
Indonesia & Romania \\
Ireland & Rwanda \\
Israel & Saint Kitts and Nevis \\
Italy & Saint Lucia \\
Kyrgyzstan & Saint Vincent and Grenadines \\
Latvia & Saudi Arabia \\
Luxembourg & Slovenia \\
Mexico & South Africa \\
Netherlands & Suriname \\
New Zealand & Thailand \\
Nicaragua & Trinidad and Tobago \\
Panama & Uganda \\
Paraguay & United Arab Emirates \\
Peru & \\
Poland & \\
Portugal & \\
Senegal & \\
Singapore & \\
Slovakia & \\
Switzerland & \\
Turkey & UnitedKingdom(including Scotland) \\
Uruguay & \\
Venezuela & \\
\hline
\end{tabular}

Source: http://prostitution.procon.org/view.resource.php?resourcelD=000772

\section{Did the legalization of prostitution affect (or it didn't ) in the decrease of the number of the trafficked person for sexual exploitation!}

We stated above that many countries have legalized prostitution, considering it as a solution of the problem of trafficking with the intention of sexual exploitation. Thus,thinking that the legalization of the prostitution shall decrease the number of trafficked women and shall protect the sex workers by making them feel not discriminated, but shall enjoy the rights equally to those of any other activity. These countries legalized prostitution by considering it as a legal activity that enjoys legal protection. However the experience of the countries that legalized prostitution shows that legalization is notthe best way thought to be, because in these countries trafficking in woman for sexual exploitation continues to be very developed, even in some countries trafficking in woman for sexual exploitation increased compared to the time before prostitution was legalized. Among these countries it is worth to mention the experience of the Dutch state, below we shall elaborate the Dutch model of prostitution by comparing it with the Swedish model. These models differ completely from each other. One of them allows prostitution, whereas the other one punishes the purchase of sexual services. However does not punish the offering of sexual services.

\subsection{The Dutch model of Prostitution}

The Dutch model of prostitution is considered unique in the world. In 2000 Netherlands adopted a law that legalized prostitution in this country; the arguments that were used pro legalization were as follows; legalization of prostitution would stop trafficking in women that were migrating for prostitution; legalization of prostitution would protect minor females from prostitution; legalization of prostitution would take prostitutes away from streets etc."Main objectives of this law were the regulation for employment of prostitutes through a system of granting licenses, protection of persons from forced prostitution, protection of minors from sexual exploitation"(Matak,S, and Vargek,A,2012,P,32).Prostitution is allowed to the persons that reached the age of 18 and clients shouldn't be younger than 16 years old. All involved persons in prostitution should bear identification documents and should be registered in the system of international taxes. The main reason for legalization of prostitution from Dutch authorities is considered to be the war against trafficking in 
persons for sexual exploitation".(Matak, $\breve{S}$, and Vargek,A,2012 P,33.).However, Did the legalization ofprostitution affect (or not) in the decrease of the number of the trafficked person for sexual exploitation in this country! The results of different researches show that legalization of prostitution didn't give any positive effect in the fight against trafficking in persons. After the legalization of sex industry in Netherlands in 2000 , the sex industry increased for 25 percent. The main argument that was put forward in Netherlands for legalization was that it would lead to prevention of trafficking in women, which migrated for prostitution.A report that was made for the Governmental Budapest Group shows that $80 \%$ of woman that were practicing prostitution in public houses in Netherlands, are trafficked from other countries.According to some data, the number of trafficked persons per year is several times higher and it goes from 1.000 to 7.000 trafficked persons, and

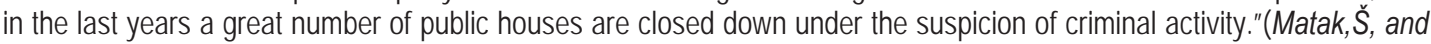
Vargek,A,2012,P.35.).Another argument that was put forward in Netherlands for the legalization of the prostitution was that this law shall help to end the prostitution among minors, but in fact the numbers show the opposite.After the legalization of prostitution the number of minors in prostitution increased for three times, this is according to an organization for protection of children rights in Amsterdam. Among this group of minors there are nearly 5000 female Nigerian children.

Table 3. Shows the number of victims of human trafficking in time period from 2000-2010

Number of victims of trafficking in persons from 2000-2010 in Netherlands

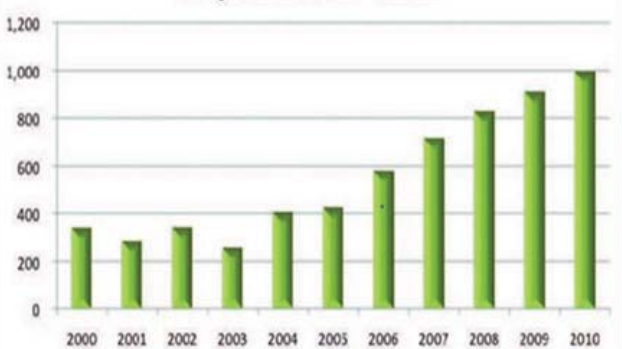

Source: http://hrcak.srce.hr/file/144606

\subsection{Swedish model of prostitution}

In 1999 Sweden adopted a law for purchase of sexual services, whereby the purchase of sexual services is considered as a crime, but not the offering of sexual services. Upon being in force of this law the results were evident.(Dreher,$A$, and Neumayer ,E, 2012 P.18).According to the data of national and local police there are more than 1000 woman currently involved in prostitution. The Swedish law foresees severe punishments toward purchasers of sexual services which will be prosecuted.The fine for sex purchasers reaches 5000 Euros.The higher the salary, the higher is the fine, i.e. depending on the annual incomes.(Kastrati, V,2013.).Except fines,another punishment for the purchaser of sexual services is the punishment imprisonment,up to 2011 maximum penalty was six months imprisonment,since 2011 punishment maximum imprisonment is one year. (The Effects of the Swedish Ban on the Purchase of Sexual Services by the March 8 Initiative, 2012,P.5).The purchasers of sexual services are considered to be people that have families and steady living, most of them when arrested accept the guilt and are ready to pay the fine even when it is too high, in order to avoid imprisonment and court sessions, and they are afraid that the fact that they are caught for prostitution will be learned by the spouses and members of their families.According to the Department of City Police of Stockholm,Anti trafficking commission, the number of prostitutes on the streets decreased evidently from 1995 where there were 650 of them on the streets. In 2010 after an inclusive investigation the number of women or girls on the streets was 175. Whereas in 2013 there are around 10 prostitutes. This situation in the area and on the streets of Stockholm in a city of about 850.000 inhabitants speaks about the success of this department and also of other institutions that work against prostitution and trafficking in persons. (Kastrati, V,2013.).So, while the countries of the world are always facing with the increase of this phenomenon, especially the countries that have legalized prostitution,in Sweden this phenomenon is decreasing. The law for selling sexual services gave positive results. But, did this affected to decrease the number of trafficked woman for sexual

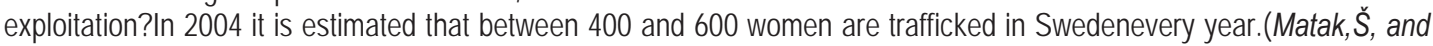
Vargek,A,2012,P.46.).The victims are Swedish women and girls and also women from Romania, Nigeria, from countries that dominate in prostitution, from Lithuania and Poland. They come in Sweden by a car, ship from Denmark, Finland, 
Germany, and Poland as tourists for seasonal or for education..(Kastrati,V,2013.).If we compare the number of trafficked females in the Scandinavian neighboring countries where prostitution is legal, Swedish law seems that it has reduced the number of trafficked persons.ILO in 2004 estimated that the number of trafficked personsfor sexual exploitation in Denmark was 2250, whereas the estimated number for Sweden was 500.This means that the number of victims of human trafficking in Denmark is more than four times of the one of Sweden. Although the number of population in Sweden (8.9 Million), is about 40\% higher than Denmark, (5.3 Million).(Drehe ,A, and Neumayer,E, 2013 P.67).Clearly it is evident that the Swedish law reduced the number of trafficked persons,compared to the countries that consider prostitution as legal activity. The provision of sexual services through the Internet in Sweden has increased during the last five years.Even though, there is no evidence that the number of people who offer sexual services online is greater in Sweden than in Denmark. According to some other reports it turns out to be the opposite.

Fig. Persons having advertized sexual services on their own on the internet in Sweden ,Norway and Denmark.20032008.

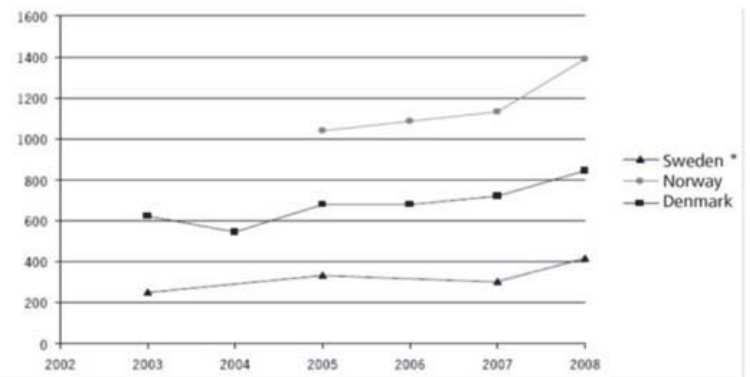

Source: http://www.8marts.dk/upl/14431/TheEffectsoftheSwedishBanonthePurchaseofSexualServicesOK.pdf

Swedish police has made an investigation about websites that advertise prostitution. Almost 200-300 advertisement in a day are posted on the Internet. In 2008 Swedish police (Division of Crime) has investigated six networks that advertise information about the prostitution and none of them were localized in Swedish Internet Servers, but outside the region. They were localized in USA,Germany,Netherlands,Denmark,Russia.(Kajsa Claude \& Swedish Institute,2010).

\subsection{German model of Prostitution}

In 2002 Germany adopted a law whereby it legalized prostitution in this country. Today prostitution is in Germany is regulated by this law and it is considered as a "regular job", it is subject to taxes and retirement contributions (Di Nicola et al., 2005). Germany is known to be on of the biggest markets of prostitution in Europe, with about 150.000 people that work as prostitutes (Drehe ,A, and Neumayer,E, 2013,P.).Annual estimations of trafficked victims for sexual exploitation in Germany show that the number of victims for sexual exploitation in Germany between 1996-1997 decreased gradually, whereas in 2001 the minimal number of victims was 9870 and the maximal was 19,740. Nevertheless this number increased after the legalization of prostitution in 2002, this number increased to $11,080-22,160$, and to $12,350-24,700$ from 2003.(Drehe ,A, and Neumayer,E,2011,P.67).In 2004 ILO estimated that in Germany there were around 32,800 trafficked victims, which is 60 times more than the number of victims in Sweden. (Aнтић, $M, \&$ Крстић, $И$, \& Делић.,J,2011, Р.14).

\section{Conclusion}

Trafficking in persons is developed in all of its forms, but the most spread one remains the trafficking for sexual exploitation purposes. The intention of this work is to explain the relationship between the legalization of prostitution and trafficking in persons, respectively to show if legalization of prostitution could influence the increase or decrease of the number of trafficked persons for sexual exploitation.By foreseeing it as a solution of the problem of trafficked women for sexual exploitation, many countries legalized prostitution, namely, thinking that legalization of prostitution would reduce the number of trafficked women, will decrease the number of women that deal with prostitution and will protect the sex workers, so that they wouldn't feel discriminated but enjoy the rights equally to those others, these countries legalized prostitution. However, legalization of prostitution doesn't seem to be the best thought solution! This is proven by the 
practices of the countries that legalized prostitution. In this work we elaborated the model of prostitution in Netherlands and Germany.

These countries legalized prostitution, and the Swedish model that completely differs from them, in order to compare these models and be able to determine if there could be and how much legalization (or not) could affect the increase or decrease of trafficked persons for sexual exploitation. The Netherlands in 2000 had legalized prostitution with the arguments that legalization would decrease the number of trafficked women for prostitution, would take prostitutes away from streets and would protect minor females from sexual exploitation.We saw that the results of different researches show that the legalization of the prostitution didn't give any positive effect toward the war against trafficking in persons. After the legalization of prostitution in Netherlands the number of trafficked persons increased several times compare to before it was legalized, especially the number of minors in prostitution increased three times more than it was before. Also in Germany it didn't give any positive result. Sweden stands in a better position which is considered to be non-attractive place for human traffickers. The Swedish law for sexual services adopted in 1999, which determines that purchasing sexual services is a crime, whilst it is not when offering sexual services,gave evident results.

Currently the number of prostitutes in Sweden is considered to be 1000, before the law was adopted in 1998 the number of women involved in prostitution was 2500, the same for the number of purchasers it dropped from $13 \%$ in 1996 , to $7 \%$, and the number of prostitutes in the streets dropped 650 in 1996 to 175 in 2010, whereas in 2013 it is estimated that there are 10.This number speaks about the success of institutions that work against prostitution and trafficking in persons in Sweden. Swedish legislation is an example followed by many countries like; Iceland, France,Norway,South Korea,Great Britain,which are at the adaptation phases of the same law. Despite the negative side, legalization of prostitution has the positive side in the aspect of protection of health of the workers by creating conditions for regular inspection, better health conditions, decreases the possibility of sexually transmitted diseases. The attempts of the countries that through the legalization of prostitution shall influence on the decrease of the trafficked persons for sexual exploitation purpose did not show to be successful, or we could even say it failed in their mission. All the efforts to bring prostitution as natural as possible, to rehabilitate it, to give legal protection and to convert it to an authentic business do not undo it which in fact prostitution is. I will close this work with the sentence used in the Universal Declaration of Human Rights adopted and announced by the General Assembly of UNO, with its resolution no. 217A/III, date 10 December 1948. That says:

'Everyone has the right to life, liberty and security of person, but in prostitution women are unsafe,threatened, and not protected.'

\section{References}

Axel Dreher-(German Institute for Economic Research, Berlin, GermanyUniversity of Heidelberg, Heidelberg, Germany) \& Eric Neumayer- (London School of Economics and Political Science, London, UK).Does Legalized Prostitution Increase Human Trafficking?Published in: World Development, 41 (1), 2013.

Axel Dreher \& Eric Neumayer.Does Legalized Prostitution Increase Human Trafficking?September 2011 (updated January 2012).GeorgGusht-Universität Göttingen.

Kuadri ligjor mbi trafikimin e qënieve njerëzore në Shqipëri dhe sfidat e hasura në praktikën gjyqësore.(Mbështetur nga projekti $\mathrm{i}$ financuar nga USAID "Fuqizimi i Kapaciteteve Shqiptare Kundër Trafikimit" i zbatuar nga IOM ) .Shkolla e Magjistraturës. Shkurt 2013. (http://www.albania.iom.int/publications/research/School\%20of\%20Magistrate\%20study\%20on\%20CT\%20issues-ALB.pdf)

Lekë Sokoli \& llir Sokoli .Trafikimi Rasti i Shqipërisë .Instituti i Sociologjisë,Tiranë.2006. http://www.cessalbania.com/pdf /Trafikimi_rasti___Shqiperise.pdf

Марко Антић доц.др Ивана Крстић Јелена Делић. Истраживачки рад у оквиру Правне клинике за сузбијање трговине људима Универзитет у Београду Правни факултет децембар 2011.

Niklas Jakobsson and Andreas Kotsadam.The Law and Economics of International Sex Slavery: Prostitution laws and trafficking for sexual exploitation .June 2010.

Protocol to Prevent, Suppress and Punish Trafficking in Women and Children, supplementary to the United Nations Convention against Transnational Organized Crime, UN Doc. A/55/383 (15 December 2000), entered into force on 25 th of December 2003.

Šime Matak,mag. iur.Ana Vargek,mag.iur.Trgovanje ljudima u svrhu seksualnog iskorištavanja - utječe li legalizacija prostitucije na smanjenje trgovanja ljudima?2012.

The Effects of the Swedish Ban on the Purchase of Sexual Services by the March 8 Initiative, November 2012 - www.8marts.dk

Violeta Kastrati-Islami ,Shembulli holandez përndjekë blerësit e seksit.Stockholm,2013 http://wmcks.com/shembulli-suedez-perndjekebleresin-e-seksit/

http://www.dcaf.ch/content/download/35416/526049/file/ALB

http://prostitution.procon.org/view.resource.php?resourcelD=000772

http://www.8marts.dk/upl/14431/TheEffectsoftheSwedishBanonthePurchaseofSexualServicesOK.pdf 